used for votive services asking God for peace. The settings are listed in a useful table (pp. 248-252), and seven of them are edited in an appendix. Leitmeir discusses in more detail a relatively homogeneous group of compositions he labels 'Rudolfine' (p. 223), connected in different ways to the court of the Emperor Rudolf II, and relates them to the zeitgeist of the era, manifest both in the emperor's desire for peace and in a more general irenic movement (pp. 209-2IO). The analysis focusses more closely on a chromatic inflection that some Da pacem settings adopt in paraphrasing the chant incipit of the antiphon. Leitmeir reads this as a 'rhetorical device to express the urgency of their petition for peace' (p. 220), and he highlights the importance of a detail that is often understood as a performative rather than compositional aspect. He identifies further occurrences of the chromatic $D a$ pacem antiphon in Philippe de Monte's $A d$ te Domine levavi (which thematises peace in its canonic inscription, pp. 238-239) and Jacobus de Kerle's Missa Da pacem (pp. 24I-247).

The last article in the volume (Jan Bat'a, 'Furor turcicus: The Turkish Threat and Musical Culture of the Czech Lands during the Sixteenth and Early Seventeenth Centuries', pp. 279-295) explores several polyphonic and monodic settings that thematise the Turkish threat. Particularly interesting is the discussion of the Officium proti Turku by the composer Jan Trojan Turnovský (d. I606), comprising a collection of polyphonic items for a votive service in Czech 'against the Turk'. Annotations in the only extant source (unfortunately lacking three of its five parts) show that this service was redirected against other enemies of the church by substituting the 'Turk' with references to a generic 'enemy', to the 'antichrist', or to a 'papist' (p. 285).

All in all, Renaissance Music in the Slavic World is a welcome publication that is both symptomatic of and instrumental to changing paradigms in music historiography. Musicology is taking note that regions which were closely connected with the rest of Europe do not appear in the dominant narratives of European music history, and it is laudable that this publication involves scholars from different institutions and with different backgrounds. As is often the case with an edited collection, the scope and breadth of the single contributions differ, but the book as a whole - commendably written mostly in English, the academic lingua franca - will certainly help generate more awareness about regions that, from a Western European perspective, are so close and yet regrettably so far away.

Antonio Chemotti

Instytut Sztuki, Polska Akademia Nauk

\title{
CONTRAFACTA. MODES OF MUSIC RE-TEXTUALIZATION IN THE LATE SIXTEENTH AND SEVENTEENTH CENTURY, EDS. MARINA TOFFETTI, GABRIELE TASCHETTI
}

Kraków 2020 Musica Iagellonica, pp. 358. ISBN 978-83-7099-239-2

$\mathrm{I}^{\mathrm{n}}$ n 2019, under the academic supervision of Marina Toffetti, the University of Padua organised an International Spring School called 'Contrafacta: Music with New Texts with New Contexts', which brought together several scholars from various
European universities. The volume reviewed here constitutes its direct outcome and is presented as the 'first survey of the contrafactum' (p. 6), with the editors also hoping that it will encourage further studies on this topic. 
The book is divided into three sections: an introductory essay by Marina Toffetti, followed by two sections devoted respectively to 'Re-thinking and Re-creating Music' and 'Re-using and Adapting Music'. The rationale for dividing the essays into two parts is not given in the book, where one would expect it, but only on the back cover, where the editors specify that the first part deals with 'procedures of textual substitution' while the second examines texts adapted for celebratory, political and confessional needs, with a strong focus on Sweden, as three of the four essays in this second part are devoted to the Düben Collection. The book concludes with an appendix comprising two tables, authored respectively by Marco Giuliani and Gabriele Taschetti, listing collections which include contrafacta from I576 to I62I, and from I646 to I649 (pp. 267-332).

Further information on the content of the book is given in the introductory essay 'Contrafacere: Retextualizing Polyphonic Music from the Late Sixteenth to the Seventeenth Century' (pp. 9-39), where Toffetti explains that the book covers contrafacta from different parts of Europe, such as Scotland, Germany, Italy, Poland and Sweden, dating from 1587 to I693. The majority of the works examined are secular or sacred polyphonic compositions, with a particular focus on genre 'transmigration', that is, secular models that became sacred contrafacta. Toffetti further clarifies that the term contrafactum is understood here in its wider meaning of 'a vocal composition of which the original text [...] has been more or less extensively modified or substituted by a new text' (p. Io), and that the essays analyse the reasons why the examined contrafacta were produced and the methods used to do so. In her essay, Toffetti argues that contrafacta are artifacts that originate a complex network of intertextual references; in order to study them, one needs to assess the new text in relation to the origi- nal, the phonetic characteristics and meaning of both texts, and the motivations for producing the contrafactum. Toffetti distinguishes between contrafacta as acts of love versus acts of violence: the former have texts that convey new meanings and revitalise a composition, while the latter betray the original (p. 17). She focuses on the aural perception of a text, through its phonetic characteristics, arguing that new texts can change the sound of a composition. On another layer, Toffetti discusses the change of meaning in relation to the transmigration of a genre, in particular from secular to sacred, showing that, due to a fundamental stylistic homogeneity between different repertoires, the texts played a crucial role in making a composition suitable for a liturgical context. The choice of a new text could also respond to another concrete need, such as making a composition in a different language understandable. As to the motives, Toffetti shows that almost all contrafacta were made for two purposes: to extend the life of a polyphonic work by making it available to new contexts, and to broaden the audience by making it suitable for devotional and liturgical contexts.

Alessandra Petrina's 'The Court of James VI of Scotland (I566-1625) and its Reception of Italian Musical Modes' (pp. 43-6o) examines the adaptation of Italian models during the Scottish Renaissance, focussing in particular on the period before the coronation of James VI as King of England. Due to its geographical distance, Scotland is a case study of extreme interest, as its reception of cultural phenomena from continental Europe is unique. Scottish contrafacta belonged to a much wider operation of adapting and translating French and Italian works. While musical traces are scarce, at least compared to other European traditions, Petrina demonstrates that contrafacta contributed to a substantial remodelling of Scottish culture, which at the time was perceived as deficient. Michael Chizzali's 
essay ('Text and Context of the Thuringian contrafactum: New Insights into Melchior Backhaus's Primus liber (1587)', pp. 6I-82), on the contrary, deals with a situation in which both theoretical and practical sources are abundant, due to the frequent exchanges between Italy and Germany in the second half of the sixteenth century. Drawing on theoretical sources, in particular Georg Quitschreiber's De Parodia, Chizzali argues that contrafacta were perceived as part of a process of literary intertextuality. He also points out that their abundance is the result of a process of internationalisation (p. 63), and that being able to make a contrafactum was a requisite for German composers. Still on German repertoire is Chiara Comparin's contribution titled 'From Venice to Nuremberg and Leipzig: Il Trionfo di Dori (1592) and its German Retextualizations' (pp. II7-I5O), which looks at the two retextings of the Italian collection Il Trionfo di Dori, namely the Musicalische Streitkräntzlein by Johann Lyttich (I6I2-I3) and the Triumphi de Dorothea by Martin Rinckart (I6I9), which modified the original with different procedures and purposes. Lyttich turned the original madrigals into strophic canzonettas, while keeping the pastoral setting, whereas Rinckart was more attentive to Lutheran prescriptions, and his choice of themes was far from the original. Furthermore, he freely adapts the original score for his aims - a procedure crucial to his work. Both collections, as Comparin demonstrates, made the Italian madrigal repertoire available in religious and educational German contexts. Marina Toffetti also wrote the essay 'Contrafacta of Palestrina's Works Printed in Milan (I597-I605)' (pp. 83-II5), in which she analyses the diffusion of Palestrina's music in Milan. Particularly interesting is the appendix listing Palestrina's music published in Milan between 1587 and I620 (pp. II2-II5). Toffetti stresses that sacred retextualisations of originally secular music helped to broaden the audience of a composition, although she argues that only a limited public would have been able to appreciate them (p. 87). She presents two case studies: contrafacta of the madrigals Io son ferito ahi lasso and Vestiva i colli. For both, Toffetti shows that Orfeo Vecchi, author of the adaptations, paid particular attention to the relationship between the new text and the original. In the case of Ion son ferito, the new text forms a gloss of the original; in Vestiva $i$ colli, meanwhile, the two texts share many similarities. Tomasz Jeż concludes the first part of the collection with his essay on Polish contrafacta ('Contrafacta of Italian Madrigals in Polish Musical Sources', pp. I5I-I70). Jeż highlights the popularity of spiritual reworkings after the Council of Trent, identifying over Ioo contrafacta produced in Poland, the majority of them being Mass and Magnificat parodies. Jeż also argues that the sacred quality of a work stemmed from the text rather than the music (p. 153), and this legitimised the presence of both secular and sacred qualities. The spiritual reworkings consist mainly of Latin motets or vernacular canzoni, and their modifications are kept to a minimum, due partly to the simplicity of the original models. Jeż shows how there was often a correspondence on syntactic and semantic levels between the originals and the contrafacta, the latter representing a 'transcription of the form' (p. I63).

The second part of the book begins with Katarzyna Spurgjasz's contribution 'Salve Jesu Christe, Rex Misericordiae: Lutheran Adaptations of Pre-Reformation Repertoire from St Elisabeth's Church in Wrocław' (pp. 173-186), which links the two sections of the book by keeping the reader's focus on the Polish context. Spurgjasz focuses her attention on two settings composed to the same text, both from the same environment, St Elisabeth's Church in Wrocław. Both contrafacta originate from pre-Reformation repertoire and are Lutheran reworkings of the antiphon Salve Regina: one is a monodic 
piece, while the other is a polyphonic work mainly homorhythmic in style. The text here, originally devoted to the Virgin Mary, has been modified and adjusted for the new Reformed context, through the alteration of just a few words. The rest of the second part of the book presents three essays strongly connected one with each other, being all focused on the Swedish Düben Collection. The order in which the essays are arranged is somewhat puzzling, as it would have been more convenient for the reader to begin with Maria Schildt's contribution ('Re-using Pre-existing Music with New Texts: Repertoire for Court and Church in Seventeenth-Century Sweden', pp. 209-245, the second essay in this section), since it provides a general overview of contrafacta in the Düben Collection. That would have facilitated the reader's understanding of the other two studies, both by Lars Berglund, which focus on specific works from the collection. Schildt shows that contrafacta contained in the Düben Collection can be divided into three categories, based on their functions. The biggest category comprises contrafacta that modify the text for theological reasons, the second is constituted by works in which the language is changed, while the third and smallest group consists of works in which the text was adapted for a specific occasion. Schildt argues that the works were selected very carefully, particularly in relation to the original texts and contexts. In Sweden too we see that the skill of producing a contrafactum was essential among composers, although Schildt demonstrates that there was no standard methodology, with each composition reworked in a unique way. Catholic texts were adapted for Lutheran rites, and the Swedish language started to be used from the end of the seventeenth century, especially in connection with the aristocracy and the royal family. In the last part of the essay, Schildt discusses the music for the funeral of King Charles X, showing how the references to Christ and the Passion conta- ined in the text of Francesco Dalla Porta's motet Obstupescite redempti were carefully substituted by references to the king and his death. As mentioned above, Lars Berglund penned two contributions on contrafacta from the Düben Collection. The first ('Arde Fillis / Isti sunt: A contrafactum by Gustav Düben, Based on a Madrigal by Stefano Landi, and Previously Attributed to Giacomo Carissimi', pp. I87-208) analyses the only example from the Düben Collection of a madrigal adapted with a sacred text, Arde Fillis, transmitted in the seven partbooks Vmhs II:2 from Uppsala University Library. The original madrigal, ascribed in the collection to Carissimi, is attributed by Berglund to Stefano Landi. Through palaeographical analysis, Berglund also shows that it was copied by Gustav Düben, the original owner of the collection. The contrafactum here is not complete, as only the first thirty-seven bars are re-texted, while the original incipit, 'Arde Fillis d'un viso', appears in the part of the second basso continuo. The new text, 'Isti sunt triomphatores', is taken from the Responsory and the corresponding verse for the Common of Apostles, and Berglund carefully analyses the ways in which the music was adapted to the new text. In his other essay, titled 'Mourning a Dead Queen: The Music at the Funeral of Ulrika Eleonora the Elder in Stockholm (1693)' (pp. 247-263), Berglund considers the sairge musique, or mourning music, for the funeral of Queen Ulrika Eleonora, along with the entire symbolic framework put together by the Swedish court to celebrate the queen. The music performed for the occasion included Daniel Danielis's motet Aspice e coelis, for which we find an extra soprano part with a Swedish text in the Düben Collection. As Berglund points out, 'it is a freely composed prose text, resembling a prayer. It is a lament of sorrow, and a prayer for grace and mercy' (p. 254). This motet was originally composed for another funeral, with the Swedish text making 
it suitable for the funeral of a member of the royal family; it was also recycled for other funerals. The volume concludes with an appendix, which provides two useful tables listing chronologically the printed collections which contain contrafacta published from 1576 to I62I, and from I646 to I649.

This book provides a good overview of the phenomenon of the re-texting and adapting of works in various parts of Europe during the late sixteenth and seventeenth century, also proposing, through the variety of essays, different methodologies that can be applied when studying these works. The various contributions, especially those that assess the phenomenon in general, such as Toffetti's introduction and Schildt's study on the Düben Collection, will serve as a starting point for further studies. The breadth of points of view that can be observed throughout the book also results in essays that vary a great deal in their analysis of the contrafacta. Some focus on the adaptation of the music and text, while others lean towards an assessment of the contexts and necessities that led to the re-workings.
While this is valuable, as it provides a good array of different perspectives, it is also the main drawback of the book. The lack of an introduction tying the various contributions together is noted by the reader and results in a book in which, more often than not, there is no strong, cogent link between the essays. This can be seen also in some editorial choices: for example, some essays provide an English translation of the analysed texts while others do not. The book is well produced, with good-quality images and clear musical examples; at the end of each essay, there is an abstract, which is a valuable addition. There are indices of names and places, though, surprisingly for a book very much focussed on works, no index of compositions. The bibliography is given only in footnotes, and it may have been useful to include either a general bibliography at the end of the volume or one at the end of each essay.

Nicolò Ferrari

University of Huddersfield

\section{MONTEVERDI IN SAN MARCO, EDS. RODOLFO BARONCINI, MARCO DI PASQUALE}

Lucca 2020 Libreria Musicale Italiana, pp. XXII+424+I6 col. illus. ISBN 9788855430357

$\mathrm{T}$ he newly published book by Libreria Musicale Italiana is not another monograph (let alone a hagiography, notwithstanding the name of the saint appearing in the title) of a famous composer. Anyone expecting an integral narrative on Claudio Monteverdi as the main agent in Venetian musical life during the first half of the seventeenth century will be slightly disappointed. It seems that Rodolfo Baroncini and
Marco di Pasquale (the editors and authors of the lion's share of the book) decided to treat Monteverdi as a single cog, albeit a particularly important one, in the musical mechanisms of Venice. Such a structural or institutional approach will be met with satisfaction by those readers who wish to learn about Monteverdi from a very wide socio-cultural perspective. On one hand, this book deals with the musical context 